\title{
Undiscovered Methemoglobinemia During Surgery and Review of Literature
}

\author{
Emilio Vazquez, Alice Jamison, Jerry Kwok \\ Oral Surgery Department, Guy's and St Thomas' NHS Foundation Trust, London, UK.
}

\section{Corresponding Author: \\ Dr. Emilio Vazquez \\ Email: emiliovazquez@live.co.uk}

This is an Open Access article distributed under the terms of the Creative Commons Attribution License (creativecommons.org/ licenses/by/3.0).

Received : February 12, 2020

Accepted : April 4,2020

Published : May 5, 2020

\begin{abstract}
Background: Methemoglobinemia is a rare condition in which there is an elevated level of methemoglobin in the blood resulting in its reduced oxygen carrying capacity, which can be induced by substances used routinely by dentists. Case Report: The author details the unanticipated event of methemoglobinemia in a 41 year old male with hypodontia undergoing anaesthetia for dental implants. An abnormal appearance of the blood followed by dropping oxygen saturation intra-operatively aided this potentially fatal diagnosis. Acute management included the delivery of methylene blue followed by liaison with hematologists to plan future procedures. Conclusion: Methemoglobinemia is of direct relevance to the dental setting in patients being administered anaesthesia.
\end{abstract}

Keywords: Anodontia, Dental Implants, Methemoglobinemia, Methylene Blue, Oxygen.

\section{Introduction}

We present an unusual case of methemoglobinemia presenting within the dental setting. Methemoglobinemia is elevation of methemoglobin $(\mathrm{MetHb})$ in the blood which hinders the release of the oxygen into the tissues. This can lead to a range of complications from the resultant hypoxia and functional anemia [1].

Local anaesthetics are known to induce this condition in susceptible individuals and there are very few reports of this in the literature [2,3]. Methemoglobinemia should be considered as a differential diagnosis in those with cyanosis or the appearance of chocolate-brown arterial blood following administration of local anaesthetic. The multidisciplinary management of the condition was paramount to successfully completing the required invasive dental surgery.

\section{Case Report}

A 41 year old, Sudanese patient was admitted for the extraction of his retained deciduous molars and placement of 10 dental implants under day case general anaesthesia. His relevant medical history included mild ectodermal dysplasia with associated severe hypodontia and asthma. His social history was unremarkable. The patient had a general anaesthetic in 1991 without complications.

The pre-operative vital signs revealed: temperature $34.1^{\circ} \mathrm{C}$, blood pressure $117 / 68 \mathrm{mmHg}$, pulse rate $65 \mathrm{bpm}$ and oxygen saturation of 99\%. General anesthesia was induced using intravenous propofol and atracurium. Other drugs administered included fentanyl, dexamethasone, paracetamol, diclofenac and ondansetron. The surgeon administered six $2.2 \mathrm{ml}$ cartridges of $2 \%$ lidocaine with 1:80,000 adrenaline via infiltrations in all four quadrants in preparation for surgery and the dental treatment was commenced. It was only when a full thickness muco-periosteal flap was raised that the appearance of chocolate-brown blood was noted; this combined with a desaturating oxygen level $\left(\mathrm{SpO}_{2}\right.$ fell from $100 \%$ to $92 \%$ during treatment) highlighted a possible abnormality which required further investigation. Capnography showed continued perfusion of both lungs but the operation was suspended in view of the continued 
poor oxygen saturation. A peripheral arterial line was inserted and blood gases obtained revealed a methemoglobin level of $27 \%$.

A provisional diagnosis of acquired methemoglobinemia secondary to lidocaine administration was made and the team agreed to cease the treatment prematurely; admitting the patient to the Intensive Care Unit (ICU). His management involved administration of methylthioninium chloride (methylene blue) intravenously. His methemoglobin levels were monitored with daily arterial blood gases which fell from $17.5 \%$ to $7 \%$ [Table 1] over the following days. The initial plan was to discharge the patient when his MetHb was below 5\% but after a week of close monitoring and remaining asymptomatic he was discharged with a follow up appointment with the hematology team.

On review with the hematology department he was found to be autosomal recessive in methemoglobinemia. On advice of the hematologist, the patient was started on ascorbic acid (100 $\mathrm{mg}$ ) once daily for a week prior to the elective surgery and the patient was readmitted for the completion of his implant surgery using total intravenous anesthesia (TIVA) with propofol and the procedure was completed without local anaesthetic for pain relief.

\section{Discussion}

Methemoglobinemia presents with an elevated level of methemoglobin in the blood which

Table 1: Methaemoglobin levels on arterial blood gas (ABG) in ICU.

\begin{tabular}{|c|c|}
\hline \multicolumn{2}{|c|}{ Methaemoglobin Levels on ABG in ICU } \\
\hline Day & MetHb (\%) \\
\hline 1 & 17.5 \\
\hline 2 & 10.4 \\
\hline 3 & 7.7 \\
\hline 4 & 7.0 \\
\hline 5 & 7.1 \\
\hline 6 & 10.7 \\
\hline
\end{tabular}

inhibits the release of the oxygen into the tissues. Methemoglobin levels in the blood are normally maintained below $2 \%$ of the total hemoglobin by the following two mechanisms: (i) 'NADH pathway' which uses cytochrome b5 reductase to transfer electrons from NADH to methemoglobin. This pathway accounts for over $95 \%$ of the methemoglobin reduction activity. (ii) 'NADPH pathway' which uses NADPH methemoglobin reductase to reduce the ferric ion to the ferrous state and accounts for less than $5 \%$ of the methemoglobin reduction activity as it is less efficient than the NADH pathway.

As the level of methemoglobin increases, the symptoms of the methemoglobinemia become more severe, ultimately resulting in death [Table 2]. There are a wide range of etiologies congenital and acquired [Table 3]; including drugs/substances [Table 4] that can exacerbate the condition by oxidizing the ferrous-containing hemoglobin into methemoglobin; including local anaesthetics [5]. As a result of this rare, yet serious consequence, methemoglobinemia is of direct relevance to the dental setting and all those administering local anaesthetic to patients. Hereditary methemoglobinemia occurs due to deficiency of reduced nicotinamide adenine dinucleotide (NADH) cytochrome b5 reductase [8] and has been categorized into 2 types: (i) Type I (erythrocyte): enzyme is only deficient in the erythrocytes. (ii) Type II (generalised): enzyme is deficient in many of the tissues.

Table 2: Symptoms related to level of methaemoglobin $[2,4]$.

\begin{tabular}{|l|l|}
\hline MetHb (\%) & Symptoms \\
\hline$<3$ & Asymptomatic \\
\hline $3-15$ & Slight discolouration of skin \\
\hline $15-20$ & $\begin{array}{l}\text { Mild cyanosis (normally apparent on the lips, } \\
\text { nail beds and mucous membranes) }\end{array}$ \\
\hline $25-50$ & $\begin{array}{l}\text { Headache, dyspnoea, light-headedness, } \\
\text { weakness, confusion, palpitations }\end{array}$ \\
\hline $50-70$ & $\begin{array}{l}\text { Abnormal cardiac rhythms, delirium, altered } \\
\text { mental state, seizures, coma, acidosis }\end{array}$ \\
\hline$>70$ & Circulatory collapse, death \\
\hline
\end{tabular}


Table 3: Etiology of methemoglobinemia [4-7].

\begin{tabular}{|c|c|}
\hline Congenital & Acquired \\
\hline $\begin{array}{l}\text { - Enzyme deficiency } \\
\text { in NADH reductase } \\
\text { (hereditary) } \\
\text { - Haemoglobinopathies } \\
\text { (e.g. Haemoglobin M } \\
\text { or B presence) }\end{array}$ & $\begin{array}{l}\text { - Local anaesthetics (topical or } \\
\text { injected) } \\
\text { - Organic and inorganic nitrates } \\
\text { (e.g. medications or contaminated } \\
\text { nutritional intake) } \\
\text { - Chlorates } \\
\text { - Dapsone } \\
\text { - Copper sulphate } \\
\text { - Recreational drugs } \\
\text { - Antimalarials } \\
\text { - Antineoplastic agents } \\
\text { - Analgesics and anti-pyrexics } \\
\text { - Zopiclone } \\
\text { - Herbicides and insecticides } \\
\text { - Indigo carmine } \\
\text { - Resorcinol } \\
\text { - Metoclopramide } \\
\text { - Antibiotics } \\
\text { - Industrial agents }\end{array}$ \\
\hline
\end{tabular}

Methemoglobinemia can also be exacerbated by dialysis and the presence of concurrent disease including heart disease, liver cirrhosis, acidosis, anaemia and the extremes of age; notably younger than 3 months old [9]. These susceptible patients are at a heightened potential of unexpected methemoglobinemia especially if high risk drugs [Table 4] are administered in large doses [10].

The diagnosis of methemoglobinemia in unexpected circumstances is vital to ensure that the correct management plan can be instigated quickly. This can be significantly difficult without the clinical input from the undue appearance of chocolate-brown blood and desaturation on pulse oximetry; therefore clinicians should be aware of this. The diagnosis can be made by a combination of blood gas analysis, pulse oximetry and multiple wavelength co-oximetry. However, a primary care dental practice are unlikely to have these monitors readily available therefore methemoglobinemia should be suspected if a patient becomes cyanosed following delivery of local or topical anaesthetics [10]. The clinical symptoms and management
Table 4: Substances with risk of inducing methemoglobinemia $[2,3]$.

\begin{tabular}{|c|c|c|}
\hline High risk & Moderate risk & Low to no risk \\
\hline $\begin{array}{l}\text { - Prilocaine } \\
\text { - Benzocaine } \\
\text { - Sulfonamides } \\
\text { - Primaquine } \\
\text { - Napthalene } \\
\text { - Nitroglycerine } \\
\text { - Acetanilid } \\
\text { - Chlorates } \\
\text { - Nitric Oxide } \\
\text { - Phenacetin } \\
\text { - Dapsone } \\
\text { - Quinine Sulfate } \\
\text { - Phenobarbital } \\
\text { - Isosorbide Dinitrate } \\
\text { - Nitrofurantion } \\
\text { - Phenazopyridine } \\
\text { - Metoclopramide } \\
\text { - Nitrates/nitrites } \\
\text { - Amyl nitrate } \\
\text { - Nitroprusside } \\
\text { - Aniline (dyes, ink) } \\
\text { - Chloroquine } \\
\text { - Paraquat } \\
\text { - Resorcinol } \\
\text { - Benzene derivatives } \\
\text { - Trimethoprim } \\
\text { - Ciprofloxacin }\end{array}$ & $\begin{array}{l}\text { - Lidocaine } \\
\text { - Nitrous oxide } \\
\text { - Bupivacaine } \\
\text { - Aspirin } \\
\text { - Acetaminophen } \\
\text { - Mepivacaine } \\
\text { - Articaine } \\
\text { - Etidocaine } \\
\text { - Fentanyl }\end{array}$ & $\begin{array}{l}\text { - Phenothiazines } \\
\text { - Meperidine } \\
\text { - Thiopental } \\
\text { - Inhalational } \\
\text { anesthetics } \\
\text { - Propofol } \\
\text { - Benzodiazepines } \\
\text { - Succinylcholine }\end{array}$ \\
\hline
\end{tabular}

are the same whether the etiology is hereditary, congenital or acquired [13].

The management of an acute onset of methemoglobinemia involves rapid assessment, removal of the offending agent (if known/possible) and commencement of supplemental oxygen; ideally placing the patient in a supine position. Failure of this warrants the use of the recognized first line treatment methylene blue. This should be given intravenously in a $1.0-2.0 \mathrm{mg} / \mathrm{kg}$ dose as a $1 \%$ solution slowly over five minutes [10-14]. The level of methemoglobin should reduce within an hour of this initial dose but if unsuccessful a second dose should be administered [13]. Methylene blue can be administered every 60 minutes with a maximum dose of $7.0 \mathrm{mg} / \mathrm{kg}$ [9]. 
Methylene blue functions as a co-factor for the enzyme NADPH-methemoglobin reductase which then converts the methemoglobin back to hemoglobin [15]. This pathway is normally the non-dominant and accounts for less than 5\% of the methaemoglobin reduction but the induction of the methylene blue as a co-factor increases the efficiency. In rare cases, individuals may not respond to treatment with methylene blue, namely those with a glucose-6-phosphate dehydrogenase (G6PD) deficiency. This is because G6PD is a co-factor in the NADPH reductase system and methylene blue requires that pathway to function. In the absence of G6PD the methylene blue will be useless. In these cases the provider should instigate second line treatment such as hyperbaric oxygen or an exchange transfusion is required [16].

An alternative antidote mentioned in the literature includes intravenous ascorbic acid. The mode of action remains uncertain but may have the ability to reduce oxidative stress [17]. For this reason a recommended dose has not been agreed but Faust et al. advises 2.5-10 g/dose IV ascorbic acid which is similar to the doses administered by Reeves et al. and Park et al. in their cases' with a total of $80 \mathrm{~g}$ (10 g/dose over $54 \mathrm{hrs})$ and $30 \mathrm{~g} \mathrm{(5 \textrm {g } /}$ dose every 6 hours) delivered respectively. These doses have been found to be successful in treating methemoglobinemia in patients where methylene blue is not appropriate e.g. patients who are pregnant or have G6PD deficiency. The avoidance of methylene blue in pregnant patients has been suggested due to the risk of intestinal atresia in the mother; however it should be highlighted that methylene blue was provided by intra-amniotic injection. The author realizes the route may have a significant impact on this complication but with hemolytic anemia and photosensitivity also reported it may be best practice to avoid its use during pregnancy until further research proves otherwise [17]. Further investigations should be performed when the patient has recovered from the acute phase to rule out underlying congenital or hereditary causes. Patients with known severe methemoglobinemia may be prescribed lifelong methylene blue (50-250 mg/day orally) or ascorbic acid (200-500 mg/day orally) [18].

Dentists should be aware of the potential for an adverse drug reaction from topical or local anaesthetics, namely benzocaine and prilocaine. It is imperative, like any drug that the maximum dose of these anaesthetics is not exceeded and therefore dentists must be knowledgeable about the dosage guidelines. Dentists need to be alerted to this potentially fatal reaction and should try to identify patients that are more susceptible. This can be highlighted in the medical history by confirming whether they have a history of previous adverse drug reactions. A patient with unexplained cyanosis should be thoroughly investigated to exclude methemoglobinemia.

\section{Conclusion}

This case highlights the need for clinical vigilance during any operative procedure. The appearance of dark/chocolate looking blood should ring alarm bells for the clinician and the anaesthetist. Management should involve a rapid multidisciplinary team response and interventions undertaken as appropriate.

Methaemoglobin is a rare condition and therefore recognition can be difficult at time of surgery. The clinician should be aware of the potential for local anaesthetic agents to elicit such a response and therefore must choose their local anaesthetic agent carefully with extra care given to the dose given in relation to the patient's body weight. Methylene blue remains the first line treatment for methemoglobinemia unless contraindicated.

Contributors: EV, AJ, JK: Conception and design, interpretation of data, drafting of the work. EV will act as a study guarantor. All authors approved the final version of this manuscript and are responsible for all aspects of the study. Funding: None; Competing interests: None stated. 


\section{References}

1. Hoffman RS, Howland MA, Lewin NA, Smith SW, Goldfrank LR, Nelson LS. Goldfrank's toxicologic emergencies. $10^{\text {th }}$ ed. New York: McGraw-Hill Education. 2015.

2. Hall DL, Moses MK, Weaver JM, Yanich JP, Voyles JW, Reed DN. Dental anesthesia management of methemoglobinemia-susceptible patients: A case report and review of literature. Anaesth Prog. 2004;51:24-27.

3. Moore PA. Adverse drug interactions in dental practice: interactions associated with local anaesthetics, sedatives and anxiolytics. J Am Dent Assos. 1999;130:541-554.

4. Denshaw-Burke M. Methemoglobinemia. Medscape; 2018. Available from: https://emedicine.medscape.com/ article/204178-overview. [Last accessed on 15/08/2019].

5. Alanazi, M. Drugs may be induced methemoglobinemia. Journal of Hematology \& Thromboembolic Diseases. 2017;6:1-5.

6. Emery A, Korf B, Pyeritz R, Rimoin D. Emery and Rimoin's essential medical genetics. $7^{\text {th }}$ ed. San Diego: Elsevier, 2018.

7. Kuji A, Satoh Y, Kikuchi K, Satoh K, Joh S. The anesthetic management of a patient with hemoglobin M-Imate. Anesth Analg. 2001;93:1192-1193.

8. Rehman HU. Methemoglobinemia. Journal of West $\mathbf{J}$ Med. 2001;175:193-196.

9. Tentindo G, Rosenburg M. Methemoglobinemia and local anaesthetic: What every dentist should know. J Mass Dent Soc. 2010;59:18-20.
10. Wilburn-Goo D. When patients become cyanotic: Acquired methemoglobinemia. J Am Dent Assoc. 1999;130:826-831.

11. Barash M, Reich KA, Rademaker D. Lidocaineinduced methemoglobinemia: A clinical reminder. J Am Osteopath Assoc. 2015;115:94-98.

12. Shamriz O, Cohen-Glickman I, Reif S, Shteyer E. Methemoglobinemia induced by lidocaine-prilocaine cream. Isr Med Assos J. 2014;16:250-254.

13. Ludwig SC. Acure toxic methemoglobinemia following dental analgesia. Ann Energy Med. 1981;10:265-266.

14. Clifton J 2nd, Leikin JB. Methylene blue. Am J Ther. 2003;10:289-291.

15. Wright RO, Lewander WJ, Woolf AD. Methemoglobinemia: etiology, pharmacology, and clinical management. Ann Emerg Med. 1999;34:646656.

16. Ashurst J, Wasson M. Methemoglobinemia: a systematic review of the pathophysiology, detection, and treatment. Del Med J. 2011;83:203-208.

17. Faust AC, Guy E, Baby N, Ortegon A. Local anaestheticinduced methemoglobinemia during pregnancy: A case report and evaluation of treatment options. J Emerg Med. 2018;54:681-684.

18. David SR, Sawal NS, Bin Hamzah MN, Rajabalaya R. The blood blues: A review on methemoglobinemia. J Pharmacol Pharmacother. 2018;9:1-5. 